DOI: http://dx.doi.org/10.33846/hn50106

http://heanoti.com/index.php/hn

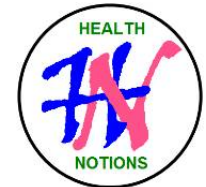

RESEARCH ARTICLE

URL of this article: http://heanoti.com/index.php/hn/article/view/hn50106

\title{
The Effect of Side Effects Tuberculosis Treatment in the Early Stage Towards
} Compliance with Tuberculosis Patients

\author{
Joko Sapto Pramono $^{1(\mathrm{CA})}$, Nilam Noorma ${ }^{2}$, Andi Lis Arming Gandini ${ }^{3}$, Sopia Fitriani ${ }^{4}$ \\ ${ }^{1(\mathrm{CA})}$ Department of Nursing, Poltekkes Kemenkes Kalimantan Timur, Indonesia; jokosp2005@ yahoo.com \\ (Corresponding Author) \\ ${ }^{2}$ Department of Nursing, Poltekkes Kemenkes Kalimantan Timur, Indonesia; andilisi20@yahoo.com \\ ${ }^{3}$ Department of Nursing, Poltekkes Kemenkes Kalimantan Timur, Indonesia; ns.nilamnoorma@gmail.com \\ ${ }^{4}$ Department of Nursing, Poltekkes Kemenkes Kalimantan Timur, Indonesia; sopeee29@gmail.com
}

\begin{abstract}
Pulmonary tuberculosis treatment causes various side effects including nausea and vomiting, itching, vision problems, and anemia. Drug side effects in the early stages are one of the causes of non-adherence to complete treatment. The purpose of this study was to analyze the effect of the side effects Tuberculosis treatment in the early stages on treatment compliance for tuberculosis patients. This study used a cross sectional design. Samples were taken as many as 71 respondents, the instruments used were side effects of early-stage tuberculosis treatment and compliance with tuberculosis treatment in tuberculosis patients from the Morisky Medication Adherence Scale (MMAS). The results of the study found $97.7 \%$ adherent and $2.3 \%$ non-adherent, $39.5 \%$ mild side effects and $60.5 \%$ severe side effects. Chi-square test showed that no significant difference between the side effects of TB treatment in the early stages of tuberculosis treatment compliance in patients $p=0.669$ at significant level of $95 \%(\alpha=0.05)$. There was no effect between the side effects of Tuberculosis treatment in the early stages of treatment compliance for Tuberculosis patients. It was recommended that health workers continue to monitor the side effects of tuberculosis treatment and provide motivation to carry out treatment completely.
\end{abstract}

Keywords: side effects; early stage; treatment; pulmonary tuberculosis; compliance

\section{INTRODUCTION}

One of the second most common infectious tropical diseases in the world. is pulmonary tuberculosis caused by the bacillus Mycobacterium tuberculosis. Tuberculosis can be transmitted through droplets from infected people. Tuberculosis is a latent disease, which means that patients have been infected but have not yet caused signs / symptoms and cannot transmit to other people and even nearly a quarter of the world's population suffers from latent tuberculosis ${ }^{(1)}$.

Tuberculosis is one of the top 10 causes of death in the world, in 2017, an estimated 10 million people suffer from Tuberculosis, even 1.6 million of them died. The reduction in the incidence of Tuberculosis globally is $2 \%$ per year, it is expected that there will be a decrease of up to $4-5 \%$ so that one of the targets for sustainable health development, namely ending the Tuberculosis epidemic can be achieved by $2030^{(2)}$.

Indonesia is ranked the second worst after India based on the Global Tuberculosis Report ${ }^{(1)}$. It is estimated that around 1,000,000 new TB cases per year (399 per 100,000 population) with 100,000 deaths per year (41 per 100,000 population). There are 25 Ministries of Health making a 2015-2019 strategic plan to reduce TB prevalence from 297 per 100,000 population in 2013 to 245 per 100,000 in $2019^{(2)}$.

Tuberculosis treatment consists of two stages, namely the initial stage (intensive) and the advanced stage. In the initial stage (early stage) it is carried out every day with a Drug Swallowing Companion (PMO) for two months, the aim is to reduce the number of germs and minimize drug resistance. The advanced stage is given to kill the remaining germs, it is hoped that the patient can recover completely and there will be no recurrence ${ }^{(3)}$. Tuberculosis treatment is given with a combination of drugs containing at least 4 kinds of drugs. The anti-tuberculosis (OAT) drug used is a combination of Isoniazid (H), Rifampin (R), Pyrazinamid (Z), Ethambutol (E) and Streptomycin (S). In Indonesia, a combination of drugs uses several categories, namely category 1 , category 2 , children category and kombipak package ${ }^{(4)}$.

In the early stages of giving Tuberculosis drugs, it must be done regularly and thoroughly to prevent recurrence and the occurrence of resistance and patients have to swallow the drug every day, so that this causes boredom, especially since each drug has side effects individually, this allows the patient not to take medication regularly. and until finished ${ }^{(5)}$.

Although Tuberculosis treatment can be completed in some patients without side effects, some of them experience side effects, from mild to severe, therefore monitoring the possibility of side effects is very important during treatment ${ }^{(6)}$. The side effects of tuberculosis treatment include no appetite, nausea, abdominal pain, joint pain, tingling 29 |Publisher: Humanistic Network for Science and Technology 
sensation, reddish urine, flu syndrome, such as fever, chills, weakness, headaches and pain ${ }^{(4)}$. There has a study of how the effect of side effect Tuberculosis treatment in the early stage towards compliance with Tuberculosis patients.

\section{METHODS}

This type of research was quantitative with analytic studies and cross sectional design. The population in this study were patients with smear positive tuberculosis in Sungai Kunjang District, Samarinda City, East Kalimantan Province, Indonesia in 2019. The sample was taken as a whole (total sampling) of 71 respondents based on index data at three health centers in May 2019. The independent variable was the side effect of tuberculosis treatment at the early stage and the dependent variable was treatment compliance. The questionnaire was used as an instrument to collect data about side effects of early stage TB treatment and treatment adherence to TB patients based on the Morinsky Medication Adherence Scale (MMAS). Collected data were analyzed descriptively with frequency distributions and to determine the effect of the drug on the side effects of treatment compliance by chi square analysis. This study was approved by ethics of Health Research Ethics Committee of Ministry of Health Polytechnic of East Kalimantan with numbers LB.03.01 / 7.1 / 2089/2020.

\section{RESULTS}

The characteristics of the respondents were more than mostly male $(55.8 \%)$, the lowest age group was at the age of 35-45 years (34.9\%), and 46-55 years totaling 24 people aged 36- 45 years (20.9\%), most of the respondents had a high school education $(60.5 \%)$ totaling 15 people and most of them had high school education 26 people $(60.5 \%)$ and a small proportion of respondents did not have a job $(25.6 \%)$.

Table 1. Characteristics of respondents

\begin{tabular}{ccc}
\hline \multicolumn{1}{c}{ Variable } & Frequency & Percentage \\
\hline Gender & 40 & 55.8 \\
1. Male & 31 & 44.2 \\
2. Female & & \\
Age & 2 & 2.3 \\
1. 12-16 & 7 & 9.3 \\
2. 17-25 & 8 & 11.6 \\
3. 26-35 & 25 & 34.9 \\
4. 36-45 & 15 & 20.9 \\
5. 46-55 & 12 & 16.3 \\
6. 56-65 & 3 & 4.7 \\
7. >65 & 10 & \\
Education & 12 & 14.0 \\
1. Elementary school & 43 & 16.3 \\
2. Junior high school & 7 & 60.5 \\
3. Senior high school & & 9.2 \\
4. Bachelor degree & 20 & 27.9 \\
Occupation & 2 & 2.3 \\
1. Housewife & 31 & 44.2 \\
2. Gov. employee & 18 & 25.6 \\
3. Self-employed & 71 & 100 \\
4. Unemployed & & \\
\hline \multicolumn{2}{c}{ Total } &
\end{tabular}

Table 2. Distribution of respondents based on drug side effects

\begin{tabular}{ccc}
\hline Drug side effects & Frequency & Percentage \\
\hline Mild & 43 & 60.5 \\
Severe & 28 & 39.5 \\
\hline Total & 71 & 100 \\
\hline
\end{tabular}

The distribution of respondents based on side effects of TB treatment in the early stages, more respondents experienced mild side effects $(60.5 \%)$ than those who experienced severe side effects $(39.5 \%)$.

Table 3. Distribution of respondents based on treatment compliance

\begin{tabular}{ccc}
\hline Compliance & Frequency & Percentage \\
\hline Obey & 69 & 97.7 \\
Disobey & 2 & 2.3 \\
\hline Total & 71 & 100 \\
\hline
\end{tabular}

The distribution of respondents based on the level of compliance with tuberculosis patients, almost all $(97.7 \%)$ of respondents were in the adherent group and very few $(2.3 \%)$ were non-adherent in treating Tuberculosis sufferers. 
Table 4. The results of the effect of side effects of tuberculosis treatment in the early stage on treatment compliance to tuberculosis patients

\begin{tabular}{|c|c|c|c|c|c|c|c|c|}
\hline \multirow{3}{*}{$\begin{array}{c}\text { Treatment side } \\
\text { effects }\end{array}$} & \multicolumn{4}{|c|}{ Compliance } & \multirow{2}{*}{\multicolumn{2}{|c|}{ Total }} & \multirow{3}{*}{$\mathrm{p}$} & \multirow{3}{*}{$\begin{array}{c}\text { OR } \\
(95 \% \mathrm{CI})\end{array}$} \\
\hline & \multicolumn{2}{|c|}{ Obey } & \multicolumn{2}{|c|}{ Disobey } & & & & \\
\hline & f & $\%$ & $f$ & $\%$ & $\mathrm{n}$ & $\%$ & & \\
\hline Mild & 41 & 96.2 & 2 & 3.8 & 43 & 100 & \multirow{2}{*}{0.669} & 0.692 \\
\hline Severe & 28 & 100 & 0 & 0 & 28 & 100 & & $(1.038-0.890)$ \\
\hline Total & 69 & 100 & 2 & 100 & 71 & & & \\
\hline
\end{tabular}

An overview of the effect of side effects of pulmonary tuberculosis treatment on treatment adherence to tuberculosis patients can be seen in table 4, which showed that side effects of mild drugs on treatment adherence are $96.2 \%$, much higher than those who did not adhere to treatment $(3.8 \%)$. While the serious side effects of treatment were all $(100 \%)$ compliant with tuberculosis treatment.

Chi square test found that there was no significant effect between the side effects of treatment in the early stages of tuberculosis patients on compliance with treatment where $\mathrm{p}=0.669(>0.05)$. The Fisher statistical test resulted in $\mathrm{p}$ value $=1.000$. The table also showed that the Odd Ratio $(\mathrm{OR})$ value is 0.962 , which meant that respondents who comply with treatment had a protective factor of 0.962 times for experiencing side effects of tuberculosis treatment.

\section{DISCUSSION}

The results of the univariate analysis found that all respondents experienced side effects of TB treatment at the initial stage (two months of routine treatment every day), most of them stated that they had mild side effects $(60.5 \%)$ and a small proportion stated that the side effects were quite severe $(39.5 \%)$. Symptoms of tuberculosis drug side effects can occur in the early or early stages of treatment in a greater dose and frequency than in the advanced stage where the dose and frequency are reduced but the treatment takes longer.

Generally, giving drugs in large quantities makes sufferers lazy to take medication. One of the causes of failure in treatment in the early stages of tuberculosis is drug side effects. Through health education and assistance in ingesting drugs by PMO cadres, it will increase patient awareness to complete treatment ${ }^{(7)}$.

Several previous studies stated that there was a significant effect between drug side effects on medication adherence, that the more severe the symptoms of drug side effects, the more patients would not adhere to treatment ${ }^{(8)}$. However, pulmonary tuberculosis treatment should be continued as long as side effects do not cause fatal conditions, it is necessary to provide additional health education and treatment to reduce complaints. However, if the patient experiences severe side effects, then treatment must be stopped, while if it was known that the cause of the side effect is a certain type, the symptoms of side effects are treated with appropriate drugs ${ }^{(9)}$.

The data showed that the level of compliance of respondents in treatment is very high, amounting to $97.7 \%$, the respondents' awareness of the importance of treatment in the early stages is supported by educational data where all have attended formal education, even most have high school education (60.5\%) and only a small proportion. who had have elementary and junior high school education (14.0\% and 16.3\%). This good level of education was in line with the respondent's very good understanding of treatment in the early stages and the bad effects of not taking full medication so that it becomes motivation to comply with treatment.

The results showed that there was no effect between the side effects of tuberculosis treatment in the early stages of treatment compliance for tuberculosis patients. where $\mathrm{p}=0.669(>0.05)$. Statistical test using Fisher obtained $p$-value $=1,000$. The table also showed that the Odd Ratio $(\mathrm{OR})$ value is 0.962 , which meant that respondents who comply with TB treatment have a risk of 0.962 times to experience the side effects of Pulmonary Tuberculosis treatment.

Anti-Tuberculosis (OAT) drugs consist of Isoniazid (H), Rifampin (R), Pyrazinamid (Z), Streptomycin (S) and Etambutol (E), each drug is pharmacologically bactericidal and has specific side effects. In general, antituberculosis drugs have side effects as follows: impaired liver function, gastrointestinal, vision and hearing balance, peripheral neuropathy, seizures, flu syndrome, red urine, thrombocytopenia, fever, skin rash, shortness of breath, hemolytic anemia, gout arthritis, pain at the injection site, shock anaphylactic, thrombocytopenia, and toxic psychosis. However, these side effects do not occur in all people who drink them and the levels vary from mild to severe, rarely found to severe and fatal conditions ${ }^{(10)}$.

The side effects of Tuberculosis treatment in the early stages are of course an uncomfortable reaction to the patient, but this does not interfere with daily activities. Before receiving pulmonary tuberculosis treatment, patients were also educated by health workers about the side effects that they might experience so that patients understood that side effects when taking anti-tuberculosis drugs were normal and could not be avoided ${ }^{(7)}$. The Public Health Center also appointed volunteer cadres to become Medicines Swallowing Assistants (PMO), thus high patient motivation and positive family support also influenced patients to remain obedient in treatment ${ }^{(11)}$.

Previous research that contradicts this research conducted by Widyastuti (2016) stated that there was a relationship between the side effects of OAT and compliance with TB patients treatment at the Pekalongan City Community Lung Health Center $\mathrm{p}=0.035$ with $\mathrm{OR}=5.33^{(12)}$.

However, other supporting research, among others, was carried out by Rahmi, et al (2017) who said that the results of statistical tests showed that there was no significant relationship between OAT side effects and tuberculosis patient compliance in treatment which stated that there was a significant negative relationship (pvalue $=0.562)^{(13)}$, a similar thing was also obtained by the results of a study conducted by Kurniawan (2011) 
which stated that statistically there was no significant relationship between OAT side effects and compliance with TB treatment $(\mathrm{p}=0.451)$, however TB patients who were not sensing ESO has a 2.42 times greater chance of complying. This difference in results was caused by the majority of respondents $(65.9 \%)$ who experienced side effects of OAT in this study were not bothered by these symptoms ${ }^{(14)}$.

The author assumes that respondents had high motivation to recover based on sufficient understanding of pulmonary tuberculosis, so that the tuberculosis treatment program in the early stages was still carried out until it was finished even though side effects are felt and of course still consult with health workers to overcome side effect problems that arise. Respondents' concern about the dangers of tuberculosis was also an impetus for a quick recovery.

The public health center which is a tuberculosis treatment center has anticipated by educating patients and families as well as training PMO cadres to be able to accompany patients, especially during initial treatment, so that patients are controlled in the discipline of completing treatment.

\section{CONCLUSION}

The conclusion of this study is that there is no effect between the side effects of tuberculosis treatment in the early stages of treatment compliance with tuberculosis patients. It is recommended for health workers to continue to monitor and provide education about the side effects of tuberculosis treatment and provide motivation to carry out the treatment until it is finished. Further researchers can make environmental and behavioral factors as variables in research to explore more about the factors that influence the increase in new cases of tuberculosis.

\section{REFERENCES}

1. WHO. Global Tuberculosis Report 2017: Leave no one behind - Unite to end TB. WHO - Technical Report Series;727. 2017. 146 p.

2. Kemenkes RI. Profil Kesehatan Indonesia 2018 [Indonesia Health Profile 2018]. 2019. 207 p.

3. Schaaf HS, Thee S, Laan L Van Der, Anneke C, Garcia-prats AJ. Adverse effects of oral second-line antituberculosis drugs in children. Expert Opin Drug Saf [Internet]. 2016;15(10):1369-81. Available from: http://dx.doi.org/10.1080/14740338.2016.1216544

4. Dirjen P2\&PL Kementerian Kesehatan RI. Terobosan Menuju Akses Universal, Strategi Nasional Pengendalian TB di Indonesia 2010-2014. Stop TB [Internet]. 2011;1-80. Available from: http://www.searo.who.int/indonesia/topics/tb/stranas_tb-2010-2014.pdf

5. Wu X, Yang J, Tan G, Liu H, Liu Y, Guo Y. Drug Resistance Characteristics of Mycobacterium tuberculosis Isolates From Patients With Tuberculosis to 12 Antituberculous Drugs in China. Front Celluler Infect Microbiol. 2019;9(November):1-11.

6. Narasimhan P, Wood J, Macintyre CR, Mathai D. Risk Factors for Tuberculosis. Hindawi Publ Corp Pulm Med. 2013;2013(ID 828939):1-11.

7. Faramita Nurani ADL. Analysis of factors effecting the performance of drug swallowing control (PMO) in assisting patients with pulmonary tuberculosis in the work area of Kamonji Community Health Center Palu, years 2012-2013. Med TADULAKO J Ilm Kedokt [Internet]. 2015;2(2):58-69. Available from: http://jurnal.untad.ac.id/jurnal/index.php/MedikaTadulako/article/view/8007

8. Gülbay BE, Gürkan ÖU, Yildiz ÖA, Önen ZP, Erkekol FÖ, Baççioğlu A, et al. Side Effects Due to Primary Antituberculosis Drugs During the Initial Phase of Therapy in 1149 Hospitalized Patients for Tuberculosis. Respir Med. 2006;100(10):1834-42.

9. Tavares A, Mendes M, Freitas S, Cravo P. Incidence and risk factors of major toxicity associated to firstline antituberculosis drugs for latent and active tuberculosis during a period of 10 years. Pneumologia. 2015;21(3):144-50.

10. Kebede A, Wabe NT. Medication Adherence and its Determinants Among Patients on Concomitant Tuberculosis and Antiretroviral Therapy in South West Ethiopia. N Am J Med Sci. 2012;4(2):67-71.

11. Febriony C, Rasmin M, Soetikno V. Analysis of tuberculosis treatment suitability and the drug supervisor' $\mathrm{s}$ role in a community health center in Pademangan subdistrict, North Jakarta. Int J Appl Pharm. 2019;11(1):2-6.

12. Widyastuti H. Faktor-faktor yang berhubungan dengan kepatuhan berobat pasien TB paru di balai kesehatan paru masyarakat kota Pekalongan. Undergraduated Thesis [Internet]. 2016; Available from: https://lib.unnes.ac.id/27967/1/6411411043.pdf

13. Rahmi N, Medison I, Suryadi I. Artikel Penelitian Hubungan Tingkat Kepatuhan Penderita Tuberkulosis Paru dengan Perilaku Kesehatan , Efek Samping OAT dan Peran PMO pada Pengobatan Fase Intensif di Puskesmas Seberang Padang September 2012 - Januari 2013. J Kesehat Andalas. 2013;6(2):345-50.

14. Kurniawan F, Widjaja NT, Maturbongs GH, Karundeng SF, Rapa FB. Kepatuhan Berobat Penderita Tuberculosis Paru Di Puskesmas, Kota Jayapura, Provinsi Papua. J Med. 2011;10(2):56-62. 